\title{
建築プロジェクトのマネジメント方式の類型化と その選択支援システムに関する研究 CLASSIFICATION OF PROJECT MANAGEMENT SYSTEMS AND SELECTING METHOD
}

\author{
市川浩司*, 古阪秀三**, 遠藤 和 義*** \\ Koji ICHIKAWA, Shuzo FURUSAKA and Kazuyoshi ENDO
}

\begin{abstract}
The construction projects are worked out in various situations and have various purposes and characters. So as to execute efficiently the building construction project, it is required to make the proper project organizations, taking into consideration various features of each project, and to execute properly management of them, and moreover it is necessary to select the construction project management which enables the above-mentioned management to be executed. This paper discusses at first the comprehensive classification of PM systems and then examines exhaustively the features of each construction project where the priority is given to quality or technology development. The authors proposed a system to evaluate and select various PM systems according to project features, using the above-mentioned methods. Some result of simulation analysis is discussed, and its validity is revealed.
\end{abstract}

Keymords: project management, procurement system, production design. analytic hierarchy process, contract

プロジェクトマネジメント, 調達システム, 生産設計, 階層化意思决定法, 工事契約

\section{1.はじめに}

建築プロジェクトは様々な背景事情、目的、性格を有 しており、個々のプロジェクトごとにこれらの特徴が異 なる。建物の用途や規模、構造などはいうに及ばず、例 えばホテルなどの接客施設では品質が重視されるのに対 して崀庫ではコストを下げることが優先されることが多 い。さらにプロジェクトの有する技術的な複雑さ、発注 者の経験の豊富さなども異なる。そして建筑プロジェク 卜を効果的に推進するためにはこれらのプロジェクトご とに異なる様々な特徵を考慮して適切なプロジェクト組 織を編成し、全体のマネジメントを行わ的ばならず、ま たそれが可能なプロジェクトマネジメント方式（以下P M方式と略す）を選択しなければならない。つまり様々 なプロジェクトの特徵に応じて適切な P M方式を選択す るという問題を解くことが必要である。

わが国ではこれらの点に関して十分な研究が行われて おらず、典型的には設計と施工を分離し総合工事業者が
施工部分を一式で請け負う方式と、設計施工一貫方式の 二つが主に利用されている。しかし建築生産の国際化、 プロジェクトの多様化たどにとるなってようやく $\mathrm{P} M$ 方 式に関する研究に関心が払われつつある状況にあると言 って良い。著者ら”はP M 方式の国際比較を行い、各種 方式の特徽と機能を明らかにしている。江ロら はコン ストラクションマネジメント方式 (以下 C M 方式と略す) とそのバリエーションを既存のシステムと比較していく つかのファセットを用意し、それらに然づき両者を位置 づける方法を提案している。また嘉納 ${ }^{3)}$ は C M 方式に対 する発注者側のニーズを分析しそのニーズが高くなって いることを指摘している。海外ではSkitmore (が、最適 な $\mathrm{P} M$ 方式の巽択のために発注者に助言を与える簡便な 方法を発表している。しかし様々なプロジェクトの特徵 に応じてより適切な P M方式を選択する方法に関する研 究は不十分な状況にある。そこで本論文では、建築の $\mathrm{P}$ $\mathrm{M}$ 方式の包括的な類型化の方法と、この類型化された $\mathrm{P}$

\footnotetext{
* 竹中工務店 - 工修

** 宗都大学:工学部建築学科 助教授. 工博

*** 工学院大学建築学科 講師・工博
}

Takenaka Corporation, M. Eng.

Assoc. Prof., Dept. of Architecture, Faculty of Eng., Kyoto Univ., Dr. Eng.

Lecturer, Dept. of Architecture, Kogakuin Univ., Dr. Eng. 
$\mathrm{M}$ 方式をプロジェクトごとに評価・選択する方法を提案 する。具体的には図1に示すような手順で論を進める。 その内容は大きく 3 つに分けることができる。

(1) P M 方式の類型化

様々な P M 方式の特徴を検討して P M 方式を効果的に 区別する要素を抽出し、これにより $\mathrm{P} M$ 方式の類型化を 行う。この類型方法によって全ての P M 方式を共通の軸 のるとに類型化する。

(2)プロジェクトの特徵の記述

建築プロジェクトはそれぞれいくつかの要素によって 特街づけられる。前述のような「高品質」や「技術の複 雑性」といった要素を抽出して個々のプロジェクトの特 徵を網羅的に記述する方法を検討する。

(3)プロジェクトの特徽に応じた P M 方式の選択

最適な P M 方式を評価・選択するために、プロジェク トの特徽の定量的な評価と、これを基準とした P M 方式 の定量的な評価を行う。そのための方法として、階層化 意思決定法（A H P : Analytic Hierarchy Process）を 用いる。これらは P M 方式の選択支援システムとして後 に詳しく述べる。A H P 手法を用いることにより、通常 発注者がプロジェクトに対してもつ定性的な要求を定量 化することができ、かつ定量化された要素を満足させる ことのできる $\mathrm{P} M$ 方式と結合することが可能である。

発注者がプロジェクトの特徵を評価すればその後は選 択支援システムが P M 方式の評価を行い、最適と目され る P M 方式を選択することができる。なお選択支援シス テムの一部を傋成するプロジェクトの特徽と P M 方式の 適合性の検討には、実態を反映させるため実務者の意見 を取り入れる。

\section{2. $\mathrm{P} M$ 方式の類型化}

内外のプロジェクト及び文献（資料(1) を調べ、様々 な P M 方式がどのような特徽によって区別されているか を書き出し、「 $\mathrm{PM}$ 方式を特徴づける要素」として列挙 した。例えば一式請負方式は表 1 の(1)〜 (6)のような特徴 で表現され、さらにベネットががそのバリエーションと して説明する「加速型」ではそれらに加えて(7)〜(9)の特 徵を挙げるこ上ができる。

様々な P M方式についてそれらを特徴づける要素を列 挙し整理した結果、P M 方式を区別する要素として表 2
の 5 項目を抽出した。これらの組み合わせによって実際 に有り得る P M 方式を制羅する事ができる。それぞれに ついて以下に説明する。

\section{a. 業務分担}

業務分担は P M 方式の特徵の最む基本的なむのである。 業務分担を表現するためにプロジェクトを構成する全業

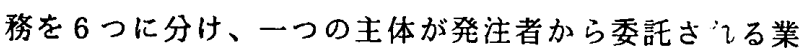
務の範囲を表す（図2）。本論文で言う業務には最近の P M 方式、C M 方式で重要な業務となりつつある生産設 計業務を独立の業務として取り上げている。

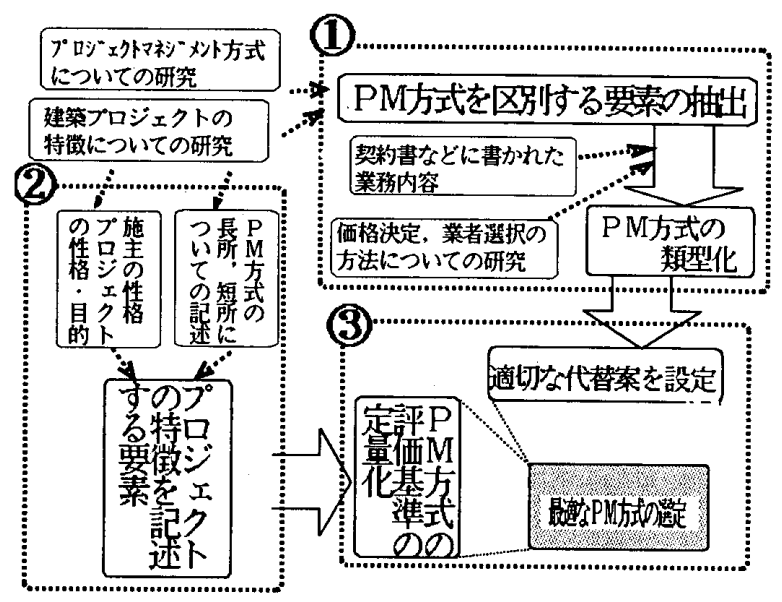

図 1 本論文の構成

\section{表 1 P M 方式を特街ゔける要素の侧}

(1)設計業務を独立の設計事務所が行う (2)工事全体を単一の総合工事業者が行う (3)完成した設計に対して工事の価格が決まる (4)発注者と総合工事業者の契約は請負契約である (5)総合工事業者が専門工事業者を雇い、調整する (6)総合工事業者が価格・品質・時間に全責任を負う (7)総合工事業者は、交涉によって選ばれる (8)総合工事業者が設計完成以前にに参加する (9)総合工事業者が設計者の生産設計業務を支援する

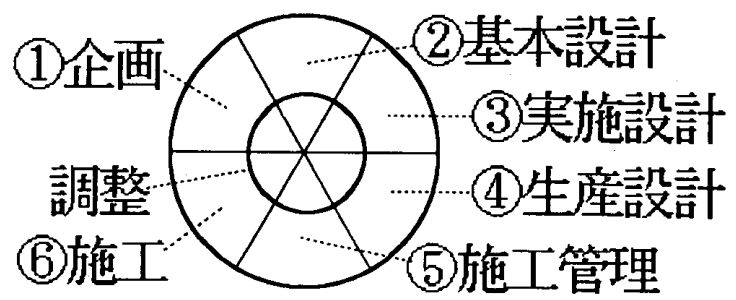

図 2 業務の 6 分割と調整業務

表 2 P M 方式の類型化のための 5 項目

\begin{tabular}{|c|c|c|c|c|}
\hline a. 業務分担 & b. 担当者 & c. 担当者の選択方法 & d. 契約のタイプ & e. 担当者の参加時期 \\
\hline $\begin{array}{l}\text { ·企画業務 } \\
\text { · 基本設計業務 } \\
\text { - 実施設計業務 } \\
\text { - 生産設計業務 } \\
\text { · 施工管理業務 } \\
\text { - 施工業務 }\end{array}$ & $\begin{array}{l}\text { ·発注者 } \\
\text { ・設計事務所 } \\
\text { ・総合工事業者 } \\
\text { ・専門工事業者 } \\
\text { ・コンサルタント }\end{array}$ & 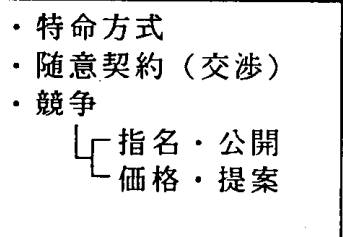 & $\begin{array}{l}\text { ·委任契約 } \\
\text { ·目標額設定型委任契約 } \\
\text { ·最高限度額保証付委任 } \\
\text { - 単価請負契約 } \\
\text { - 総価請負契約 }\end{array}$ & $\begin{array}{l}\text { ·企画段階 } \\
\text { ・基本設計段階 } \\
\text { ·実施設計段階 } \\
\text { ・八札段階 } \\
\text { ・施工段階 }\end{array}$ \\
\hline
\end{tabular}


さらに各業務の本来の内容である「基本業務」と区別 して、その業務を円滑に進めるために必要な「調整業務」 を設定する。この業務は特に C M 方式など、従来の設計 者と施工者という対立的概念に加えて、その間の円滑な コミュニケーション・調整をはかる業務の分担を、より 正確に表現することを意図している。プロジェクトを構 成する担当者間の連絡などは従来の方式では各業務の担 当者が個々に行っていたが、C M方式ではコンストラク ションマネージャー（ＣＭr）が全 6 業務にわたってこ の調整業務を担当することにより、担当者間の良好な関 係や技術的なフィードバックが可能となる。6 業務の基 本業務とその調整業務の内容に関しては契約書など（資 料(2)）を参考に定めた。

b. 業務の担当者

分割された業務の担当者が誰であるかは $\mathrm{P} M$ 方式の主 要な特徴の一つである。各業務の担当者は表 2 の $\mathrm{b}$ に示 す 5 項目で表す。例えば上記の一式請負方式は（独立し た）「設計事務所」が設計業務を担当することにより設 計施工一貫方式と区別される。

c. 担当者の選択方法

各業務担当者の選択方法を特命 - 随意契約（交渉）. 競争に分け、さらに競争については競争の内容と公開性 で区別する。例えば上記の「加速型」では総合工事業者 を「特命」で決定することによりプロジェクトでの早期 参加が期待できる。特命は随意契約の極端な例と言える が、日本で多く採用されていることから独立の選択方法 とした。

\section{d．発注者と担当者との契約のタイプ}

委任契約と請負契約を両極端とする価格に関する取り 決めを契約のタイプとして 5 項目設定する。例えば請負 契約では工事価格が契約時に決定し発注者はコストに関 するリスクを回避できるのに対して、委任契約であれば 価格は実費清算になるので発注者自身によるコストコン トロールが可能であり必要である。このような価格に関 する取り決めがざまざまな P M 方式で工夫され、その方 式を特徴づける。

\section{e . 担当者の参加時期}

プロジェクトの進行する段階を 5 段階に分け、各業務 の担当者の参加時期を表現する。参加の夕イミングは $\mathbf{P}$ $\mathrm{M}$ 方式の主要な特徴の一つで、実際のプロジェクトでも 施工者が設計段階から参加できる工夫の例が見られる。 ここでは「生産設計段階」を設定していない。理由は、 生産設計がプロジェクトによって異なるタイミングで行 われ、また必ずしもある段階にまとめて行われるむので はないからである。

以上の考察により決定した類型方法を図式化して図 3 に示す。この方法ではまず「 $\mathbf{a}$ ，業務分担」を示す。例 では全体が 4 つに分けられる。この 4 つの部分に対して $\lceil\mathrm{b}$ 。担当者」以下 4 項目を確定するという手順で類型 化を行う。実際のプロジェクトです 5 項目の決定は $\mathrm{a} \sim$ eの順で行われることが多いが、「b，担当者」久下の 4 項目の决定は相互に影響を及ぼし、それらの決定の順 序は個々のプロジェクトにより異なるといって良い。

3.プロジェクトの特徵の記述

建筑プロジェクトを特徵づける要索を文献など（資料 (3)から抽出した。「「M方式を選択する」目的に照ら してこれを表 3 に示す 2 つ要素群に分類する。 要素群(1)：評価対象 P M 方式を限定する要素

最適な P M 方式を選択するためには、まず評価対象と なる $\mathrm{P} \mathrm{M}$ 方式を設定することから始めなければならない。 すなわち評価・選択の対象となる P M 方式は、前項で述 ベた網羅的な P M 方式の中でプロジェクトの特徴から一 定程度絞り込むことが可能であり、そうすることで効果
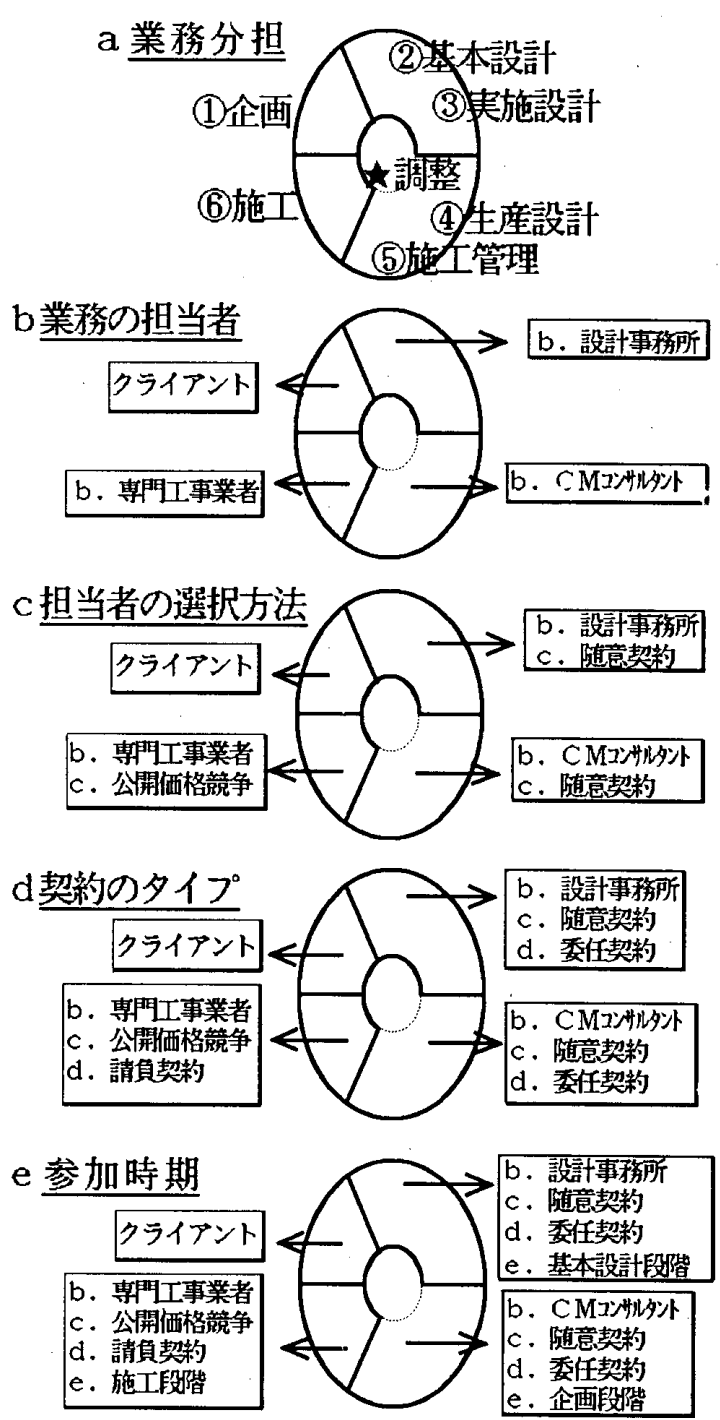

(図中の a b c d e の訲は表 2 に符合する)

図 3 P M 方式の類型化の例 
的な選択を行う。例えば現行の公共発注制度では施工の 担当者を競争的に選ぶことが前提となる。プロジェクト の性格から P M 方式の代替案として適当なるのを限定す るための条件として列挙したものが要素群(1)である。こ の要素群(1)をむとに評価対象 P M 方式を限定する要素と して実務者インタピューを参考に再構成したものが図 4 である。先に示した公共発注の例では「プロジェクトの 公共性」一「選択の公開性」一「施工者選択の公開性」 から、施工担当者の選択方法は「競争」に限定され、そ れが可能な P M方式に評価対象が限定される。

要素群(2):プロジェクトの特徵を規定する要素

本論文ではプロジェクトの特徴に対する個々のP M 方 式の有効性の差異によって P M方式を評価する。このた めにはプロジェクトの特徴の評価と、プロジェクトの特 徴と $\mathrm{P} M$ 方式を対応させるための評価の 2 つが必要であ る。そこでまずプロジェクトの特徽の評価のための要索 を文献などから抽出した（表 3 ）。この要素群(2)をプロ ジェクトの特徴を規定する要素として再構成したすのが 図 5 のレベル 1 からレベル 3 である。この図の階層構造 については後にA H P 手法のところで述べる。

$\square \mathrm{PM}$ 方式の効用を規定する要素

プロジェクトの特徵に基づいて P M方式の有効性を評 価するために P M 方式の効用を規定する要素を抽出する。 P M 方式の効用を規定する要素は、個々のP M 方式を明 快に区別・評価できること、ならびにプロジェクトの特 徵を規定する要素と対応させることができることが必要 である。これらを文献から抽出し、網羅性を考慮して決 定した 19 項目が、図 5 のレベル 4 である。
表 3 プロジェクトの特徽

要素群(1)評価対象 P M方式を限定する要素

口発注者や建物のタイプによる限定

口発注者組織の性格による限定

$\square$ 商慣習や固定的取引による限定

口継続的プロジェクトの性格による限定

$\square$ 特殊・小規模工事心性格による限定

要素群(2)プロジェクトの特徽を記述する要素

口着工前に価格や工期を確定することの必要性

口予定の価格や工期を確実に達成することの重要性

$\square$ 早期完成の重要性

$\square$ 低価格化の重要性

口高いデザィン性の重要性

口高い品質を保っことの必要性

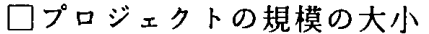

口設計変更の可能性

$\square$ 技術的複雑性

$\square$ 発注者の経験の豊富さ

$\square$ 責任の一元化の必要性

$\square$ 発注者の参加意欲

ロコストの明示性

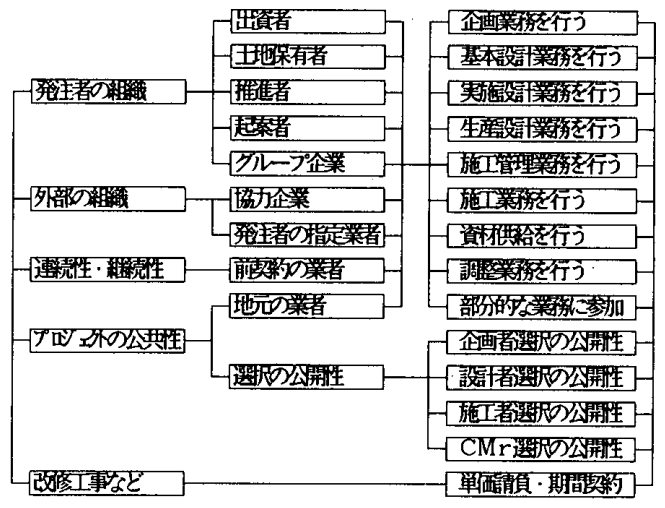

図 4 評価対象 P M 方式を限定する要素

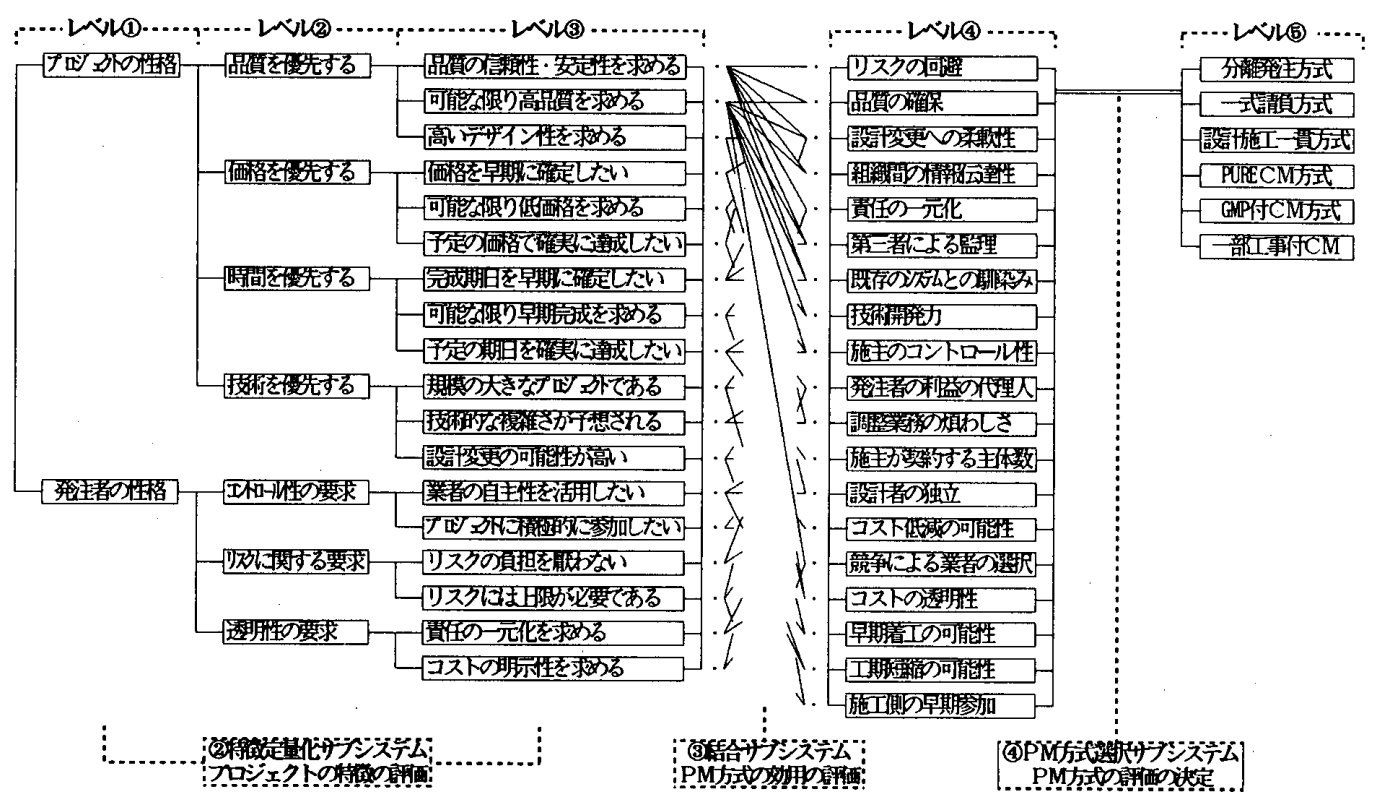

図 5 P M 方式の評価に用いる要素の階層構造 
4.PM方式選択支援システム

ここでは前節で整理された評価対象 P M 方式を限定す る要素、プロジェクトの特徽規定要素、P M 方式の効用 規定要素の定量化にA H P 手法を適用して、最適な P M 方式を選択するシステムを構筑し、その試行実験を行う。

\section{1 A H P 手法の概説}

A H P 手法の基本的な考え方は評価しようとしている 要素 2 項目ずつを「一対比較」し、優劣の評価を 5 段階 程度で主観的に与えることにある。これにより要素間の 定性的な関係の評価を定量化することができる。3 項目 以上の問題では 2 項目ずつを取り出し、全ての組み合わ せについて一対比較を行うことにより 2 項目間の問題に 還元し、定量的に評価することができる。この性質を使 って、本論文ではプロジェクトの特徽と P M 方式の効用 の定量化を行う。

A H P 手法のむう一つの特徴は、代替案の評価に用い られる評価基準が多くの場合階層的構造をとることであ る。評価基準は大分類 - 中分類 - 小分類などの階層を成 し、各階層で枝分れを繰り返し、全体として図 6 の様に になる。

\subsection{A H P に基づく P M 方式選択支嗳システムの構築}

P M 方式選択支援システムは、大きくは代替案を設定 するサブシステムと設定された代替案の評価・選択を行 うサプシステム群の 2 つから構成されている。さらに詳 細には以下の 4 つのサブシステムから構成されている。 その相互の関係は図 7 のとおりである。

（1）代替案を設定するサブシステム

(1)評価対象となるP M 方式を抽出するサブシステム ：代替案設定サブシステム

（2）代替案の評価・選択を行うサブシステム群 (2)プロジェクトの特徵を定量化するサブシステム

: 特徽定量化サブシステム

(3)プロジェクトの特徵と P M 方式の効用を結合する サブシステム

: 結合サブシステム

(4) P M 方式の効用に基づき $\mathrm{P} M$ 方式を選択するサブ システム

：PM方式選択サブシステム

以下各サブシステムの概要を記述する。

(1)代替案設定サブシステム

A H P 手法ではいくつかの代替案をあらかじめ用意す る。本論文ではこのしくみを「代替案設定サブシステム」 と呼び、代替案を評価するサブシステムと区別する。原 則的には網羅的な P M 方式から最適な P M 方式を選択で きるが、より効率的に選択すること、ならびに現実に存 在しないP M方式などを排除することなどの理由からこ のサブシステムが機能することとなる。したがって、こ のサブシステムでは評価対象となる $\mathrm{P} \mathrm{M}$ 方式として適当
なむのが限定される。前述の通りこの要素は要素群(1)と 実務者インタビューの知見をもとに作成しだ。

(2)特徽定量化サブシステム

代替案を評価するサブシステム群の中で、プロジェク トの特徵を規定する要素にウェイトを付与していく過程 が「特徴定量化サブシステム」である。図 5 に示卜よう に再構成されたプロジェクトを規定する要素を、烷注者 がプロジェクトの性格、規模、目的などに照らして A H $\mathrm{P}$ 手法の一対比較法にしたがって相対評価を行い、最終 的にレベル(3)のプロジェクトの特徵を規定する要素にウ ェイトを付与するのである。こうしてプロジェクトの特 徵が定量的に表現される。この作業はプロジェクトごと に行われる。

(3)結合サブシステム

結合サブシステムはプロジェクトの特徴と P M 方式の 効用とを結びっけるためのしくみである。つまり、ある 「プロジェクトの特徴」に対してどのような効用がどの 程度有効かを評価する。たとえば図 5 のプロジェクトの 特徵を規定する要素のうち、「可能な限り早期完 艾を求 める」に対して、P M方式の効用である「早期着工の可 能性」、「工期短縮の可能性」、「施工側の早期参加」 などの項目がどの程度有効かを評価するのである。この 評価はプロジェクトごとに行うすのではなく、本来経験 值や実際のデータに基づいて客観的に定めるべきもので ある。しかし実態として入力すべきデータは存在してお らず、この評価値は実務者のインタビューを参考に A H

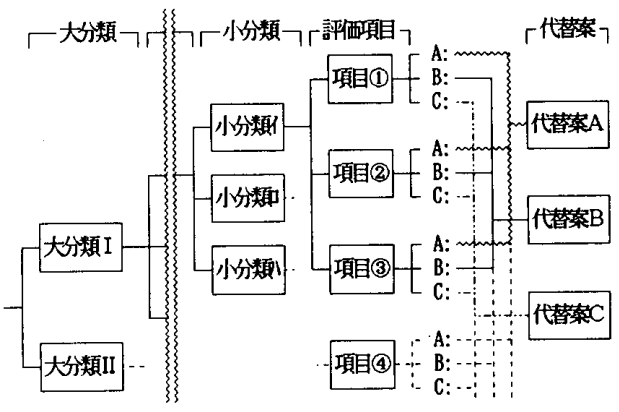

図6 A H P 手法による分析のための階層構造

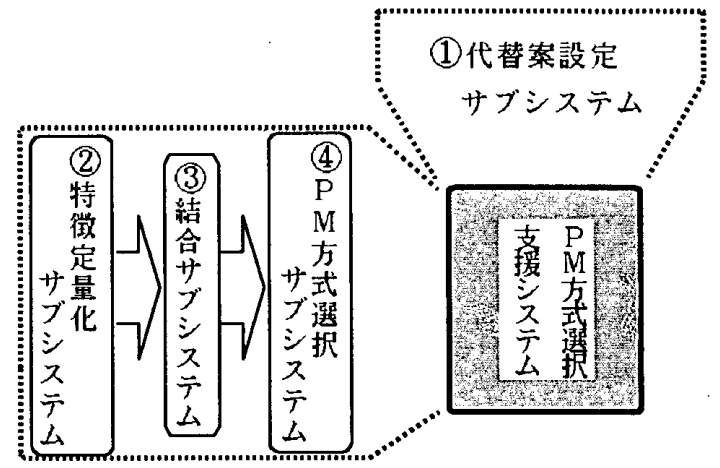

図 7 P M 方式選択支援システムの4つのサブシステム 
$\mathrm{P}$ 手法に基づいて決定した(注1)。なお、P M 方式の効用 を規定する要素は前述のごとく 19 項目にまとめられて いる（図5レベル4）。

(4) P M 方式選択サブシステム

P M 方式選択サブシステムは P M 方式の効用を規定す る要索（レベル4）と P M方式（レベル 5 ）とを結合す るしくみである。つまり、ある「 P M 方式の効用を規定 する要素」に対してどの $\mathrm{P} M$ 方式が有効かを評価する。 たとえば図 5 の効用を規定する要素のうち、「工期短縮 の可能性」に対して、評価対象の P M 方式である「一式 請負方式」、「設計施工一貫方式」、「PURE C M 方式」 「一部工事付き C M (注2)」などがどの程度有効かを評価 するのである。この評価むプロジェクトごとに行うすの ではなく、過去の実績データに基づいて客観的に定める べきすのである。しかしこの点です有効なデータは存在 しておらず、実務者の経呀值を参考に A H P 手法に基づ いて決定した。こうしてゥェイト付けされた評価基準を 使って、評価対象のP M 方式の評価を行う。このしくみ をPM方式選択サブシステムと呼ぶ。

\section{3 P M 方式選択支援システムの実行と入出力情報}

P M 方式選択支援システムの実行は、(1)代替案設定サ ブシステムの実行による評価対象 P M 方式の抽出と、(2) 特徵定量化サブシステムの実行に始まる。とくに(2)特徴 定量化サブシステムにより、発注者はプロジェクトの特 徵を規定する要素を一対比較で相対評価を行い、その結 果を本システムに入力する。その後はすべてシステム内 部で処理が行われる。すなわちプロジェクトの特徵を規 定する要素にウェイトが付与され、そのウェイトをもと に結合サブシステムにおいてPM方式の効用を規定する 要素のウェイトが確定する。さらにそれらの効用を全体 としてどの程度満足させることができるかを計算し、P $\mathrm{M}$ 方式ごとに出力する。算出された值が最も大きい $\mathrm{P} M$ 方式が本システムで最適な P M方式として選択されたす のとなる。実際に採用するかどうかは $\mathrm{P} M$ 方式を決定す る立場にある意思決定者が判断すべきすのである。表 4 にその入出力の一例を示す。

発注者は、まずレベル1において「プロジェクトの性 格」と「発注者の性格」の一対比較を A H P 手法の考え 方に従って行い、それぞれに与えるウェイトを計算する。 表 4 では極端な例を想定し、前者が0.9、後者が0.1のウ ×イトとなっている。両者のウェイトの合計は1.0になる。 次にレベル 2 に移る。「プロジェクトの性格」は「品質 を優先する」、「価格を優先する」、「時間を優先する」、 「技術を優先する」の 4 つの要素から構成される。これ らの要素についてあ A H P 手法の一対比較法によってゅ ×イトづけを行う。表 4 はそれぞれ0.1、0.7、0.1、0.1 のウェイトになっている。すなわち価格を優先する要求
が強いことを意味している。同様にして「発注者の性格」 の構成要素にもウェイト付けを行う。さらに下位うレべ ルについてす同様の比較を行い、ウェイトづけをする。

このようにしてプロジェクトの特徴を規定する要素す ベてにウェイトづけが行われると、その後は P M 方式選 択支援システム内で計算が行われ、表 4 の右闌のような 計算結果が出力される。この例では「分離発注方式」に 0.068 、「一式請負方式」に0.062、「設計施工方式」に 0.110 などの值が与えられている。この值が最も大きい $\mathrm{P}$ M方式がこのプロジェクトの特徵に最も合致した方式を 意味し、この例では「PURE C M 方式」が選択されること になる。

\section{$4.4 \mathrm{PM}$ 方式選択支援システムの試行とその結果}

発注者の要求ならびにプロジェクトの特徵としに、極 端なものを以下のように5 例想定し、P M 方式選択支援 システムに入力して、最適な P M 方式の選択を行った。 その結果を表 5 に示す。なお、ここでは簡単化のために 評価対象 P M 方式を図 5 に示す 6 方式に限定した。

例(1)コストの低減を重視

例(2)早期完成を重視

例(3)責任の一元化を重視

例(4)すべてを任せたい

例(5)要素の全てを均等のバランスにした、いわば

特に主張がない平均的な発注者

(1)コストの低減を重視

コスト低減を重視するため、レベル1では「プロジェク クトの性格」に大部分のウェイトがかけられており、レ ベル 2 では「価格を優先する」、レベル 3 では「低価格 を追求する」に大きなウェイトが付与されている。それ 以外の要素についてはウェイトを均等に配分している。

\section{表 4 A H P 手法に基づく評価の入出力の例}

【人力】

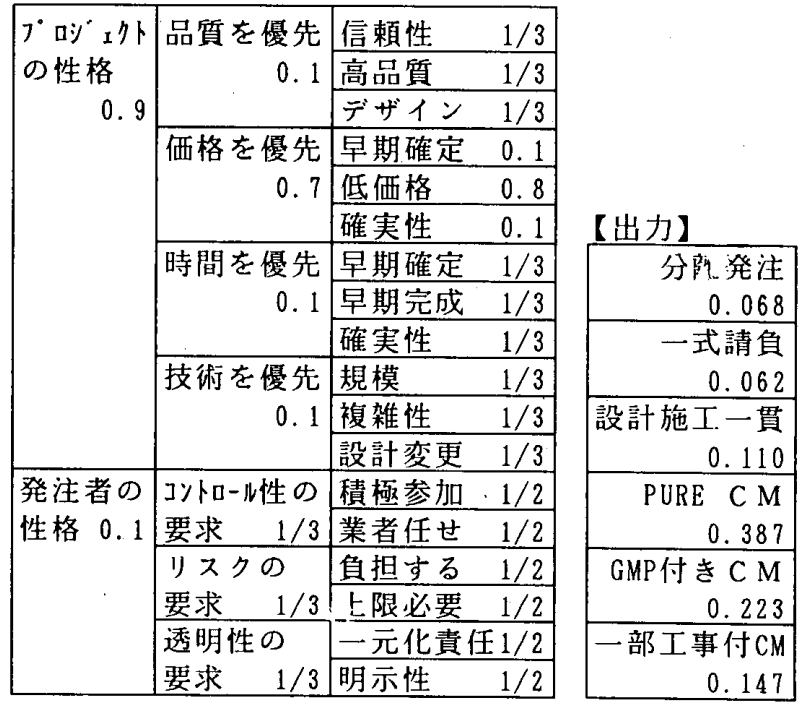


選択結果は「PURE C M 方式」が最善のP M 方式で、次い で「 G M P 付き C M 方式」となった。

(2)早期完成を重視

早期完成を重視するため、レベル1では「プロジェク トの性格」に大部分のウェイトがかけられており、レべ ル 2 では「時間を優先する」、レベル 3 では「早期完成 を追求する」に大きなウェイトが付与されている。それ 以外の要素についてはウェイトを均等に配分している。 選択結果は「PURE C M 方式」が最善のP M 方式で、次い で「設計施工一貫方式」となった。

(3)貴任の一元化を重視

責任の一元化を重視するため、レベル1では「発注者 の性格」に大部分のウェイトがかけられており、レベル 2 では「透明性の要求」、レベル 3 では「責任の一元化」 に大きなゥェイトが付与されている。それ以外の要素に ついてはウェイトを均等に配分している。選択結果は 「設計施工一貫方式」が最善のP M 方式で、次いで「一 式請負方式」となった。

(4)すべてを任せたい

プロジェクト推進上の様々な業務、責任などすべてを 任せたいとする発注者は多い。そのような発注者を想定 したもので、レベル 1 では「発注者の性格」に大部分の ウェイトがかけられており、レベル3では「業者の自主 性」、「リスクには上限」、「責任の一元化」に大きな ウェイトが付与されている。それ以外の要素については ウェイトを均等に配分している。選択結果は「設計施工 一貫方式」が最善のP M方式で、次いで「一式請負方式」 となった。

(5)要索の全てを均等のバランスにした、いわば特に主張 がない平均的な発注者

とくに要求のない発注者は、すべての要素についてウ エイトを均等に配分して考える。選択結果は「PURE C M 方式」が最善のP M方式で、次いで「設計施工一貫方式」 となった。

\section{5. まとめ}

（1） P M方式の包括的な類型化方法を検討した結果、 a . 業務分担、 b. 業務の担当者、c．担当者の選択方 法、d．契約のタイプ、e．担当者の参加時期、の 5 項 目の各要素の組み合わせにより、あらゆる $\mathrm{PM}$ 方式を網 羅する類型仙ぶ可能なことがわかった。PM方式の類型 化と網羅性は本論文で提案した P M 方式の選択支援シス テムが有効となるための前提条件である。

（2）様々なプロジェクトの特徵に応じて適切な P.M方 式を選択するという問題に対して、A H P 手法を使って 解く方法を $\mathrm{P} \mathrm{M}$ 方式の選択支援システムとして提案した。 いくつかの試行計算結果から、その妥当性之有効性が確
認できた。

（3）選択支援システムの一部を構成するプロジェクト の特徴と $\mathrm{P} M$ 方式の適合性の検討に、実態を反映させる ため実務者の経験值を取り入れたが、この部分は過去の 実績データに基づいて各観的に定めるべきものである。 有効なデータが存在していないためのやむを得ない措置 ではあるが、今後の検討課題である。

（4）本論文で提案したPM方式の選択支援システムは、 全体としてまだ開発途上であり、今後さらに検討を加え たい。とくに、A H P 手法の考え方を利用した部子に関 して、ファジィ意思決定法やエキスパートシステムの援 用を考えたい。

表 5 P M方式選択支援システムの入出力の例

\begin{tabular}{|c|c|c|c|c|c|c|}
\hline & 例(1) & 例(2) & 例(3) & 例(4) & 例(5) \\
\hline \multirow[t]{2}{*}{ レベル 1} & プ哭 外性格 & $\underline{0 .} \underline{90}$ & 0.90 & 0.10 & 0.10 & 0.67 \\
\hline & 発注者の性格 & 0.10 & 0.10 & 0.90 & 0.90 & 0.33 \\
\hline \multirow[t]{7}{*}{ レベル 2} & 品質を優先する & 0.10 & 0.10 & 0.25 & 0.25 & 0.25 \\
\hline & 価格を優先する & 0.70 & 0.10 & 0.25 & 0.25 & 0.25 \\
\hline & 時間を優先する & 0.10 & 0.70 & 0.25 & 0.25 & 0.25 \\
\hline & 技術を優先する & 0.10 & 0.10 & 0.25 & 0.25 & 0.25 \\
\hline & 羿外-n性の要求 & $\underline{0} \underline{3} \underline{3}$ & 0.33 & 0.10 & $\underline{0}=\underline{4} \underline{0}$ & 0.33 \\
\hline & 败に関する要求 & 0.33 & 0.33 & 0.10 & 0.30 & 0.33 \\
\hline & 透明性の要求 & 0.33 & 0.33 & 0.80 & 0.30 & 0.33 \\
\hline \multirow[t]{18}{*}{ レベル 3} & 品賀の信頼性 & 0.33 & 0.33 & 0.33 & $\underline{0}=\underline{3} 3$ & 0.33 \\
\hline & 高品質を追求 & 0.3 & 0.33 & 0.33 & 0.33 & 0.33 \\
\hline & 高いデザイン性 & 0.33 & 0.33 & 0.33 & 0.33 & 0.33 \\
\hline & 価格の早期確定性 & $\underline{0}=10$ & 0.33 & 0.33 & 0.3 & 0.33 \\
\hline & 低価格追求 & 0.80 & 0.33 & 0.33 & 0.33 & 0.33 \\
\hline & 価格の確実な達成 & 0.10 & 0.33 & 0.33 & 0.33 & 0.33 \\
\hline & 期日の早期確定性 & 0.33 & 0.10 & 0.33 & 0.33 & 0.33 \\
\hline & 早期完成追求 & 0.33 & 0.80 & 0.33 & 0.33 & 0.33 \\
\hline & 期日の確実な達成 & $0.3 \overline{3}$ & 0.10 & 0.33 & 0.33 & 0.33 \\
\hline & 嫢模の太きさ & $0.3 \underline{3}$ & 0.33 & 0.33 & 0.33 & 0.33 \\
\hline & 技術的複雑さ & 0.3 & 0.33 & 0.33 & 0.33 & 0.33 \\
\hline & 設計変更の可能性 & 0.33 & 0.33 & 0.33 & 0.33 & 0.33 \\
\hline & 業者の自主性活用 & 0.50 & 0.50 & 0.50 & 0.80 & 0.50 \\
\hline & 運営に積極参加 & 0.50 & 0.50 & 0.50 & 0.20 & 0.50 \\
\hline & リ즈ク負担する & 0.50 & 0.50 & 0.50 & 0.20 & 0.50 \\
\hline & リスクの上限要求 & 0.50 & 0.50 & 0.50 & 0.80 & 0.50 \\
\hline & 責任の一元化要求 & $\underline{0} . \underline{50}$ & 0.50 & 0.80 & 0.80 & 0.50 \\
\hline & コスト明示性 & 0.50 & 0.50 & 0.20 & 0.20 & 0.50 \\
\hline \multirow[t]{6}{*}{ 出力 } & - 分缸発注方式_ & 0.069 & 0.058 & 0.041 & 0.042 & 0.059 \\
\hline & & 0.063 & 0.072 & 0.181 & 0.170 & 0.091 \\
\hline & & 0.110 & 0.236 & 0.346 & 0.339 & $0.20]$ \\
\hline & PURE CM 方式 & 0.387 & 0.265 & 0.152 & 0.161 & 0.280 \\
\hline & GMP & 0.223 & 0.213 & 0.144 & 0.154 & 0.207 \\
\hline & & & 0.156 & 0.135 & 0.133 & 0.153 \\
\hline
\end{tabular}

参考文献

1) 古阪秀三、古川修、遠藤和義 ：建筑つ゚ロジェクトマネジメント方式の国際比 較 (1)，(2) 第5，6回建築生産と管理技術シンボジウム論文集 1989.90

2）三芳翃用、江口視、池田敬三：コンストラクションマネジメントの方式分類

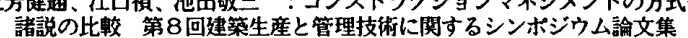
諸説の比較 第8回建築生産と管理技術に関するシンポシウム論文集

3）嘉枘成男：建築プロジェクトにおけるCM方式；発注者のCM方式に対

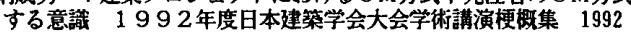

4) Skitmore, Ronald Martin Marsden, D. E. : \$hich procurement system? Towards a universal procurement selection technique. Construction Management and Economics 1988, 6, 71-89

5) Bennett, John Grice, Tony :Procurement System for Building. Qu. ity Surveying Techniques: New Directions. p. $243 \sim n .261,1990$

【資料(1)】 
Bennett, J. : 建設のプロジェクトマネジメント 1985

Nahapiet, H. :A conparison of contractual arrangements for building projects. 1985

Skitmore, R.M. : : which procurement system? Towards a universal procurement selection technique. (Construction Management and Economics 988, 6, 71-89) 1988

Bennett, J. :Procurement System for Building. 1990

建設コンサルタンツ協会 : 米国のCM実態調查報告書 1991

保証事業会社協会. : 欧米におけるCMなど建築生産方式の動向 1992

The Aqua Group. :Tebders and Contracts for Building -Second Edition. BSP 1990

三芳. 江口. : コンストラクションマネジメントの方式分類諸説の比較 1992

Haltenhoff, C.E. :The Forms and Variations of the CM System (Construction Management, A State-of-the-Art Update), ASCE. 1986

Gilbreath, R. D. : :Managing Construction Contracts. 1992

【資料(2)

四会連合協定 工事請負䄪款

建設省告示 1206 号

建築家の業務 ：新日本建筑家協会. 1992

CMAA Manua 1 : Construction Management Association of America. 1988

Leighton, P. : A Review of Current Contract Documents. (Construction Management, A State-of-the-Art Update), ASCE. 1986

CII. : Impact of Various Construction Contract Types and Clauses on Project Performance (CONSTRUCTION INDUSTRY INSTITUTE). 1986

【資料(3)

Collins, R. G. : Alternative Contract Strategy for Building and Cons'. Iction Projects. 1988

The Aqua Guroup. :Tebders and Contracts for Building. -Second Edition. BSP. 1990

Skitmore, R. M. : : Cntract Bidding in Construction. 1989

Skitmore, R. M. . : Which procurement system? Towards a universal procurement selection technique. (Construction Management and Economics $1988,6,71-89) 1988$

Tatum, C. B. and Fawcett, R.P. :Original Alternatives for Large Projects. ASCE. 1986

建設コンサルタシツ咕会. : 米国のCM実態調查報告書 1991

Surrivan, A. Harris, F. C. :Delays on Large Construction Projects. 1985

Scott, P. and Showalter, E. :The History of CM Develpopment. 1986

Leighton, P. :A Review of Current Contract Documents., ASCE. 1986

保証事業会社協会 ：欧米におけるCMなど建築生産方式の動向 1992

【一般参考文献】

古阪、迳藤、朴、吉村：「設計と施工の絰合化に関する研究（1）－設計段院

における技術情報」(第7 回建筑生産と管理技術シンボジウく)

【A H P関連参考文献】

中野大樹: : 意思決定における効用関数の利用に関する研究 修士論文 (京都大学) 1986

刀根 葶 : ゲーム感覚意思決定法 (日科技連出版)

刀根、真鍋 : A H P 事例集 (日科技連出版)

木下栄蔵：かかりやすい意思決定入門 (塸学出版)

注釈

1)アンケートの対象となった実務者は2名である。1 人はゼネコンの海外担当者、1

人はイギリスでの実務経娩の長い皘算事務所経営者。2つの結果を単純に平均するこ

とは適切でないので、本論文の評価値は後者から得な結果に基ついている。またこの

評価値の一部を、結合サフシステテとPM方式選択サブシステムのそれぞれに付いて

示守。

結合サブシステム

品筫の信頼性、安定性を求める

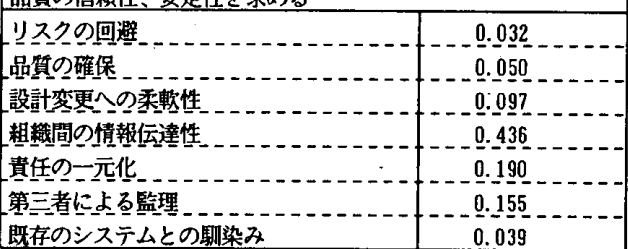

PM⿱丶万仒式選択サブシステム

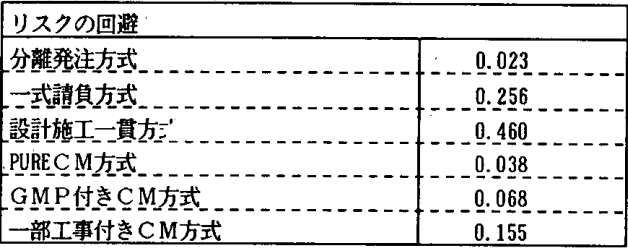

2) CM業務の守備範囲には、純䎦にマネジメント業務を行う場合の他、最高限度類保 証を設定する場合や共通仮設など一部の工事を含む場合がある。これらをそれぞれ 「PURECM方式」，「GMP付きCM方式」，「一部工事付きCM方式」と呼んでい 3.

(1993 年 4 月 26 日原稿受理，1993 年 11 月 9 日採用決定 